\title{
Platypnea-orthodeoxia Syndrome: An Important Cause of Morbidity in Post Coronavirus Disease Patients
}

\author{
Divendu Bhushan ${ }^{1} \odot$, Vijay Kumar $^{2} \odot$, B Hilbert Sahoo $^{3}$, Aniketh Hegde $^{4} \odot$
}

\begin{abstract}
Platypnea-orthdeoxia syndrome (POS) is a clinical scenario where patient get breathless while sitting or standing. Its important causes are cardiac shunts, hepatopulmonary syndrome and pulmonary ventilation perfusion mismatch. During this pandemic as cases of pulmonary fibrosis increased, we find POS as one of the important cause of morbidity during recovery. Early recognition of this will decrease the morbidity and unrealistic expectation of fast recovery.

Keywords: Happy hypoxia, Platypnea, Pulmonary fibrosis.

Indian Journal of Critical Care Medicine (2022): 10.5005/jp-journals-10071-24126
\end{abstract}

Platypnea-orthodeoxia syndrome (POS) is a condition characterized by breathlessness increased during sitting or standing. A fall of $\mathrm{SaO}_{2}$ of $>5 \%$ or $\mathrm{PaO}_{2}$ of $>4 \%$ from lying to sitting position is essential for diagnosis. ${ }^{2}$ Important causes are intracardiac shunts, atrial myxoma, hepatopulmonary syndrome, and pulmonary ventilation perfusion mismatch. Regional difference in pulmonary ventilation and perfusion found in conditions like Interstitial lung fibrosis, viral, or fungal pneumonia. ${ }^{2}$ Association of this syndrome with Interstitial lung disease which primarily involves upper lobes and cause ventilation perfusion mismatch had also been seen. ${ }^{3}$

Here, we describe a case of post coronavirus disease-2019 (COVID-19)-POS syndrome. A 55-year-old male presented with moderate COVID at the time of admission. He was maintaining saturation $>94 \%$ with $8 \mathrm{~L}$ of oxygen by face mask. He improved gradually in next 10 days with steroids and other supportive management. His oxygen requirement decreased to $3 \mathrm{~L}$ by nasal prong. We noticed that his oxygen saturation was $98 \%$ while lying down, and when he tried to sit, his oxygen saturation used to drop to $<80 \%$ and also associated with breathlessness. Arterial blood gas analysis is shown in Table 1. Screening for cardiac and hepatic cause turned out to be negative. We screened him for cardiac and hepatic disease, which was normal. CECT chest was done which showed fibrosis in bilateral upper and lower zones (Fig. 1). Patient was continued on oxygen therapy while in sitting position.

In COVID-19, there is involvement of lower and posterior part of lungs. So, the gravitational shunting of the blood to these areas results in ventilation perfusion (V/Q) mismatch. ${ }^{4}$ This is exaggerated by simultaneous occurrence of micro thrombosis and pulmonary microangiopathy in COVID-19 infection. Early detection will reduce the morbidity, unnecessary alarms, improves patient safety, and allow adjustment in rehabilitative process. ${ }^{5}$ During this pandemic, lungs are the most common organ to be affected and having acute, subacute, and chronic (post-COVID/long COVID) involvement. It presents as acute respiratory distress syndrome, acute Interstitial disease, and cryptogenic organizing pneumonia. Treatment
${ }^{1-4}$ Department of General Medicine, All India Institute of Medical Sciences, Patna, Bihar, India

Corresponding Author: Divendu Bhushan, Department of General Medicine, All India Institute of Medical Sciences, Patna, Bihar, India, Phone: +91 9661216010, e-mail: drdivendubhushan@aiimspatna.org

How to cite this article: Bhushan D, Kumar V, Sahoo BH, Hegde A. Platypnea-orthodeoxia Syndrome: An Important Cause of Morbidity in Post Coronavirus Disease Patients. Indian J Crit Care Med 2022;26(3): 401-402.

Source of support: Nil

Conflict of interest: None

Table 1: Arterial blood gas analysis at supine and sitting position

\begin{tabular}{lcc}
\hline & In supine position & In sitting position \\
\hline $\mathrm{pH}$ & 7.409 & 7.479 \\
$\mathrm{PCO}_{2}$ & 34.4 & 32.3 \\
$\mathrm{PO}_{2}$ & 74 & 53.3 \\
$\mathrm{HCO}_{3}$ & 21 & 22 \\
\hline
\end{tabular}

involves oxygen supplements, steroid, supportive treatment, and pulmonary rehabilitation. Antibiotics have limited role in this viral infection-both in acute and chronic phases. As post viral super infection is common and especially because of Staphylococcus, antibiotics are required. Steroid is a double sword, its good effect in moderate disease has been proven and injudicious use leading to super infection with bacteria and fungus are well described in literature. In chronic phase, if there is evidence of alveolitis, it can be extended till the inflammation subside.

To conclude, POS is a serious clinical syndrome which require pulmonary rehabilitation and oxygen therapy in cases of postCOVID-19 fibrosis.

(-) The Author(s). 2022 Open Access This article is distributed under the terms of the Creative Commons Attribution 4.0 International License (https://creativecommons. org/licenses/by-nc/4.0/), which permits unrestricted use, distribution, and non-commercial reproduction in any medium, provided you give appropriate credit to the original author(s) and the source, provide a link to the Creative Commons license, and indicate if changes were made. The Creative Commons Public Domain Dedication waiver (http://creativecommons.org/publicdomain/zero/1.0/) applies to the data made available in this article, unless otherwise stated. 


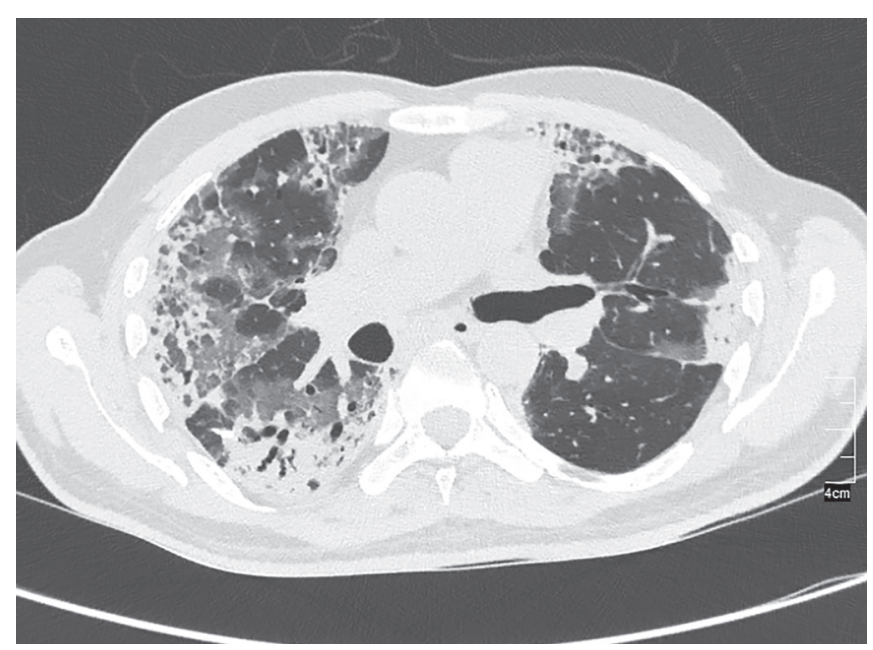

Fig. 1: Patchy areas of consolidation with air bronchogram, tractional bronchiectasis with linear opacities in bilateral lung field

\section{ORCID}

Divendu Bhushan (1) https://orcid.org/0000-0002-8718-5890

Vijay Kumar $\odot$ https://orcid.org/0000-0001-6042-7784

B Hilbert Sahoo 이 https://orcid.org/0000-0003-2847-5609

Aniketh Hegde (10 https://orcid.org/0000-0001-8708-5278

\section{References}

1. Rodrigues P, Palma P, Sousa-Pereira L. Platypnea-orthodeoxia syndrome in review: defining a new disease? Cardiology 2012;123(1):15-23. DOI: 10.1159/000339872.

2. Katsoulis K, Minasidis I, Vainas A, Bikas C, Kontakiotis T, Vakianis P. Platypnea and orthodeoxia associated with Pneumocystis jiroveci and Cytomegalovirus pneumonia: a case report. J Med Case Rep 2009;3:9319. DOI: 10.1186/1752-1947-3-9319.

3. Takhar R, Biswas R, Arora A, Jain V. Platypnoea-orthodeoxia syndrome: novel cause for a known condition. BMJ Case Rep 2014;2014:bcr2013201284. DOI: 10.1136/bcr-2013-201284.

4. Tan GP, Ho S, Fan BE, Chotirmall SH, Tan CH, Lew SJW, et al. Reversible platypnea-orthodeoxia in COVID-19 acute respiratory distress syndrome survivors. Respir Physiol Neurobiol 2020;282:103515. DOI: 10.1016/j.resp.2020.103515.

5. Aayilliath KA, Singh K, Ray A, Wig N. Platypnoea-orthodeoxia syndrome in COVID-19. BMJ Case Rep 2021;14(5):e243016. DOI: $10.1136 / \mathrm{bcr}-2021-243016$. 